\title{
THE EFFECTIVENESS OF RECOMBINANT CHITINASE OBTAINED FROM BARLEY (Hordeum vulgare L.) AGAINST POTATO PATHOGENS
}

\author{
KHAN, A. ${ }^{1 *}-$ TABASSUM, B. $^{2}-$ AALIYA, K. ${ }^{2}-$ TARIQ, M. $^{2}-$ NASIR, I. A. ${ }^{2}-$ HASSAN, ${ }^{2}{ }^{2}-$ \\ ISMAIL, T. ${ }^{3}-$ ALI, N. ${ }^{4}-$ PONYA, Z. ${ }^{3}$ \\ ${ }^{I}$ Department of Microbiology, BUITEMS, Quetta, Pakistan \\ ${ }^{2}$ Center of Excellence in Molecular Biology, University of the Punjab, Lahore, Pakistan \\ ${ }^{3}$ Department of Plant Protection and Production, Kaposvar University, Kaposvar, Hungary \\ ${ }^{4}$ Department of Botany, Hazara University, Mansehra, Pakistan \\ *Corresponding author \\ e-mail:anwarleo2003@gmail.com,anwar.khan1@buitms.edu.pk
}

(Received $8^{\text {th }}$ Dec 2018; accepted $8^{\text {th }}$ Feb 2019)

\begin{abstract}
Globally, fungi and fungi-like organisms, with over 8,000 species, cause more plant diseases than any other group of plant pests. Chitinases possess an anti-fungal role in disease resistance. They represent the pathogen-related protein group that cleaves $\beta-1,4$-glycoside bond of chitin present in the cell wall of filamentous fungi by catalysing the hydrolytic cleavage. In this study, we have amplified 672 base pair (bp) coding regions of the plant chitinase gene of Hordeum vulgare, over-expressed in Eschercia coli (E. coli) host BL21 DE3 strain by $0.5 \mathrm{mM}$ Isopropyl $\beta$-D-1-thiogalactopyranoside (IPTG) induction. In western blotting, the recombinant chitinase protein transferred on nitrocellulose membrane was detected at $26 \mathrm{kDa}$ with histidine-tagged antibody reactions. By applying the nickel charged sepharose column affinity chromatography method, a single purified band of recombinant chitinase protein was found at 26 $\mathrm{kDa}$ in SDS-PAGE. The purified recombinant chitinase protein during the agar well diffusion method inhibited the growth of three phytopathogenic fungi in a significant way; Alternaria alternate, Rhizoctonia solani and Fusarium oxysporum in qualitative in-vitro antifungal assays. The purified recombinant chitinase protein showed up to $82.6 \%$ reduction in A. alternate hyphal growth; $77 \%$ reduction of hyphal growth in Rhizoctonia solani and 78\% reduction of Fusarium's hyphal growth in invitro quantitative antifungal assays, thus depicting a strong antifungal potential. Conclusively, plant derived chitinase genes are superior in protecting the crops from phytopathogenic fungi if cloned in a suitable plant vector and expressed.
\end{abstract}

Keywords: antifungal response, early blight, Fusarium oxysporum, Rhizoctonia solani

\section{Introduction}

Fungal diseases have a deleterious impact on crops and consequently on the economy in direct, measurable terms. The extent of yield losses for major crops such as rice, wheat, maize, potatoes and soybean as the result of an epidemic outbreak vary, but a major threat to food security persists globally (Ramirez-Cabral et al., 2018). Oerke (2006) found that 26-30\% of global yield losses of crops including sugar beet, cotton and wheat are due to fungal pathogens, while this number is $40 \%$ for potatoes and $37 \%$ for rice. Currently, fungal infections destroy approximately 125 million tons of crops including rice, wheat, maize, potatoes, and soybeans each year. Some of the world's greatest famines and the resulting human suffering can be blamed on plant pathogenic fungi and fungi-like organisms (FLOs). Fungicides are primarily used on fruit and vegetable crops and approximately $97 \%$ of potato crops are treated with fungicides 
(Kaonga et al., 2018). The fungicides including Maneb, Mancozeb, cymoxanil, dimethomorph hexaconazole, iprodione, isoprothiolane and thia bendazole are sprayed on vegetables (Bentley et al., 2006; Stadlinger et al., 2018).

The most devastating among them include Alternaria alternate, Rhizoctonia solani and Fusarium oxysporum. Alternaria alternate causes early blight in tomato and potato, has a worldwide distribution and has been considered one of the most important foliage diseases in areas with warm wet conditions in the early crop season. The symptoms include tuber blight and leaf spot on potato; fruit rot and stem lesions on tomato. Rhizoctonia solani is a soil-borne fungus that causes economically important diseases in many crop species, such as sugar beet, potatoes, tomatoes, rice, rape, maize, soybean and others (van Lenteren et al., 2018). The disease caused by Rhizoctonia solani include stem canker and black scurf in potatoes, fruit rot in tomatoes, sheath blight in rice, Rhizoctonia crown and brace root rot in maize, root and stem rot in soybean crop and root rot in canola (Melzer et al., 2016). Fusarium oxysporum is a soil borne phytopathogen cause economical loss around the globe. It not only causes yield reduction but also accounts for dry rot on potato, sudden death syndrome in soybean, crown rot and head blight on the wheat and bakanae disease on rice (Bentley et al., 2006; Munkvold, 2017).

Various chemical fungicides and breeding methods for selection of natural resistant varieties are in practice to meet the fungal problem. But the selection of resistant variety is not up to mark to control fungi. The excessive use of chemical spray with about15-20 application per growing season, not only have a harmful effect on targeted pest but also on beneficial organisms in addition to hazardous environmental effects. The cell wall of the fungus is a complex structure, composed of chitin fiber and glucan held together by protein. Chitin is considered to be the second most abundant polysaccharide in the universe, composed of $\mathrm{N}$-acetylglucosamine(Nakkeeran et al., 2016). The concentration of the chitin differs among fungi, as yeast cell wall composed of $1-2 \%$ chitin while Aspergillus contains $10-20 \%$ of chitin by dry weight. F oxysporum contain $25-35 \%$ chitin in its cell wall (Becker et al., 2016). The primary role of chitin is to provide structural integrity but it also functions as linkage between cell wall and the capsule. Disruption of the fungal cell wall has severe effect on the morphology resulting in osmatic instability of the cell wall which leads to cell death (Cushion et al., 2018). It is, therefore, hypothesized that chitinase can have potential as an antifungal agent.

Chitinase an enzyme which cleaves $\beta$-1,4-glycoside bond of chitin by catalyzing its hydrolytic cleavage (Jitonnom et al., 2011). Chitinases belong to pathogen-related protein (PR) group in plants. Initially, when discovered, PR protein was considered as defense protein only as it was induced only in response to an infection but later it was revealed that PR protein has a potential role in abiotic stress also (Lincoln et al., 2018). The fact that plant chitinases act as a shield against plant fungi is well established (Fesel and Zuccaro, 2016). Plant chitinases are part of various groups of enzymes which differ with respect to their structure, enzymatic properties, and cellular localization. They are endo-chitinases and are present in stem, seed, tuber and flowers. Plant chitinases are categorized in 5-6 classes based on amino acid structure.

The aim of the present study was to isolate and over express barely chitinase II gene and evaluate its antifungal activity against major plant fungi including Alternaria alternate, Rhizoctonia solani and Fusarium oxysporum that cause yield loss to important crops. 


\section{Materials and methods}

\section{Isolation of chitinase gene from barley}

Seeds of Barley (Hordeum vulgare L.) variety Haider-93 were kindly obtained from Ayub agriculture research center, Faisalabad, Pakistan and were grown in CEMB field, Lahore, Pakistan. Total RNA was isolated from the young, immature leaves using TriZol reagent (Invitrogen). cDNA was prepared by cDNA synthesis kit (Thermoscientific) according to the manufacturer instructions. Chitinase II gene specific forward (BLP-F) and reverse (BLP-R) primers were used to amplify 889 bp gene fragment (Table 1). For amplification, reaction mixture comprised of $1 \times$ PCR reaction buffer, $0.1 \mathrm{mM}$ of dNTPs, 1 pmole each of forward and reverse primer, 1 unit of Taq DNA polymerase (Thermoscientific) and $50 \mathrm{ng}$ of template cDNA. PCR reaction was carried out in a thermal cycler (GeneAmp PCR system 9700, ABI) with the following thermal cycling parameters: initial denaturation at $95^{\circ} \mathrm{C}$ for $4 \mathrm{~min}$ followed by 35 cycles of $94{ }^{\circ} \mathrm{C}$ for $30 \mathrm{~s}, 60{ }^{\circ} \mathrm{C}$ for $30 \mathrm{~s}$ and $72{ }^{\circ} \mathrm{C}$ for $30 \mathrm{~s}$ and a final extension of $7 \mathrm{~min}$ at $72{ }^{\circ} \mathrm{C}$. Amplified products were resolved on $1 \%$ agarose gel and visualized under UV transilluminator (Biotop, Pakistan). Amplified gene fragment was cloned into pCR2.1 TA cloning vector and transformed into E. coli DH5 $\alpha$ competent cells. The cloning was confirmed by restriction digestion and sequencing. Further, the deduced gene sequence was submitted to GenBank database for accession number.

\section{Cloning and over-expression of chitinase gene}

For over-expression of chitinase II gene in E. coli, pET 30a vector (Novagen) was used. For directional cloning, BglII and NcoI restriction sites were added at $5^{\prime}$ in BLPetF and BLPetR primers (Table 1) to amplify 762 bp gene fragment. Cycling conditions were the same as above. Further, the amplified 762 bp chitinase gene fragment was codon optimized from IDT (Integrated DNA Technologies) and cloned in fusion with His tag in the pET30a vector. Further, the ligated product was transformed in chemically competent E. coli BL21 (D3) strain for expression studies.

\section{Recombinant protein expression}

Approximately, 22 different transformed colonies of BL21 (D3) were screened for over-expression of recombinant protein. Out of these, only three colonies were subjected to enhanced protein expression. Fast induction method opted for suboptimal yields of the recombinant protein by using a different concentration of IPTG $(0.1 \mathrm{mM}$ to $1.5 \mathrm{mM}$ ) and induction time.

\section{Purification of His tag recombinant protein}

The induced culture was pellet down and sonicated at 50\% duty cycle with short pulses of $35 \mathrm{~s}$ each for $15 \mathrm{~min}$. The tube was centrifuged and the pellet was resuspended in $20 \mathrm{mM}$ Tris- $\mathrm{HCl}(\mathrm{pH}-8)$ supplemented with $2 \mathrm{M}$ Urea, 2\%triton, $1 \mathrm{mM}$ EDTA and $500 \mathrm{mM} \mathrm{NaCl}$. After centrifugation, the pellet was washed with 1XPBS Buffer inclusion bodies were resuspended in 1 XPBS buffer containing $0.5 \%$ Triton X-100 and $2 \mathrm{M}$ urea). This was kept at room temperature for $35 \mathrm{~min}$. The detergent was removed by five times washing with sterilizing distilled water. Inclusion bodies were finally solubilized in buffer containing $6 \mathrm{M}$ guanidine $\mathrm{HCl}, 20 \mathrm{mM}$ Tris- $\mathrm{HCl}, \mathrm{pH} 8.0$ and $0.5 \mathrm{M} \mathrm{NaCl}$ stirred subsequently for $1 \mathrm{~h}$ at room temperature. Crude protein was 
quantified by (Kruger, 2002). Finally, the protein was purified using Chelating Sepharose Fast Flow (Amersham) through Nickel. The column was equilibrated with $6 \mathrm{M}$ guanidine $\mathrm{HCl}$ and protein was loaded on equilibrated column at the rate of $1 \mathrm{ml} / \mathrm{min}$. then washing was done with $1 \mathrm{X}$ PBS containing $0.5 \mathrm{M} \mathrm{NaCl}$ and $20 \mathrm{mM}$ imidazole. The protein was eluted in 1X PBS containing $0.5 \mathrm{M} \mathrm{NaCl}$ and $200 \mathrm{mM}$ imidazole. The eluted protein was Dialysed against $50 \mathrm{mM}$ phosphate buffer $\mathrm{pH} 6.5$ for $24 \mathrm{~h}$ at $4{ }^{\circ} \mathrm{C}$ and diluted in refolding buffer $(100 \mathrm{mM}$ Tris- $\mathrm{HCl} \mathrm{pH} \mathrm{8,} 0.5 \mathrm{M}$ L-arginine, $0.2 \mathrm{mM}$ EDTA) with constant stirring.

Table 1. Sequence of primers used to amplify the chitinase gene fragment from $\mathrm{H}$. vulgare

\begin{tabular}{c|c}
\hline Name & Sequence (5'-3') \\
\hline BLP-F & TAGTTAGCATGGCGCGGTA \\
BLP-R & TCATACGACACGATCAACTGG \\
BLPetF & GGCAGATCTGTCATCACGCAATCGGTGTA \\
BLPetR & GGCCCATGGGAAGTTTCGCTGGGTGTAGC \\
\hline
\end{tabular}

\section{Western blot}

After purification of the recombinant protein SDS-PAGE was run. The protein was transferred on nitrocellulose membrane using semidry Trans Blot (Bio Rad) transfer. The transfer was carried at $12 \mathrm{~V}$ for $40-50 \mathrm{~min}$. The membrane was blocked in $5 \%$ skimmed milk overnight at $4{ }^{\circ} \mathrm{C}$. Following day, membrane was removed from blocking solution and membrane was washed three times with 1X PBS buffer for 10 min each. The membrane was incubated with His tag anti rabbit primary antibody (1:500; Santa Cruz) in $1 \mathrm{X}$ PBS for $1 \mathrm{~h}$ with gentle shaking at room temperature. After washing the membrane with 1XPBST the Alkaline Phosphatase conjugated secondary antibody was added at 1:15000 and incubated at room temperature for $1 \mathrm{~h}$ with gentle shaking. After washing the membrane with 1XPBST the purple color was developed by NBT/BCIP tablet (Sigma). The reaction was stopped with autoclaved distilled water.

\section{In-vitro antifungal assay}

\section{Qualitative assay}

The phytopathogenic fungi Rhizoctonia solani, Alternaria alternate and Fusarium oxysporum were kindly obtained from USDA. For the antifungal assay, cylinder plate method of (Kirubakaran and Sakthivel, 2007; Toufiq et al., 2018) was adopted with some modifications. The $2 \mathrm{~mm}$ patch of the fungi to be tested was inoculated on potato dextrose agar (Oxoid) plate in the centre and kept at $28^{\circ} \mathrm{C}$ for $72 \mathrm{~h}$ for growth. Three cylinders were made around the plate edges which refer to control, $70 \mu \mathrm{g}$ and $100 \mu \mathrm{g}$ of purified chitinase protein. In the control cylinder, sterilized water was poured. Resulting fungal growth retardation/inhibition of fungi was observed after $48 \mathrm{~h}$ of protein inoculation. The results were repeated in triplicate.

\section{Quantitative assay}

The inhibitory effect of recombinant chitinase protein on the hyphal growth of $A$. alternata, $R$. solani and $F$. oxyporum was evaluated as previously described by (Khan et al., 2017; Plascencia-Jatomea et al., 2003). Wells were made on potato dextrose agar 
(Oxoid) plate and filled with $40 \mu 1$ of respective fungal spores suspension $\left(10^{4}\right.$ spores per ml) followed by incubation at $28^{\circ} \mathrm{C}$ for overnight. Further, in each well inoculated with respective fungi, $30 \mu \mathrm{g}, 50 \mu \mathrm{g}, 70 \mu \mathrm{g}, 100 \mu \mathrm{g}$ of the purified chitinase protein was added and incubation was continued at $25^{\circ} \mathrm{C}$ for 5 days. The control well was contained only the fungal inoculum and instead of recombinant protein, protein extraction buffer was added. Subsequently, the radial growth of respective fungi was recorded every $24 \mathrm{~h}$ for 5 days. The distance between the control hyphal edge to the centre - the distance between the treated hyphal edge to the centre) / the distance between the hyphal edge to the centre in the control] $\times 100 \%$ (Plascencia-Jatomea et al., 2003). The results were replicated in triplicate.

\section{Results}

\section{Over-expression of recombinant chitinase gene}

Full-length Class II chitinase gene of 889 bp was successfully amplified from barley. Deduced sequences from recombinant TA clone were analyzed for the potential coding region through the CDD (Conserved Domain Database), and the sequence was submitted to NCBI Genbank and accession \# KC899774 was obtained. Figure 1 depicts the isolation of chitinase gene and restriction digestion of chitinase gene in pET30a vector.

Further, the amplified 762 bp gene fragment was directionally cloned in pET30a, under the control of $\mathrm{T} 7$ promoter by using BglII and NcoI restriction enzymes. Successful cloning was depicted by restriction digestion of the recombinant plasmid pET:Chill. The appearance of the vector at $\sim 5.4 \mathrm{~kb}$ and gene fragment at $\sim 762 \mathrm{bp}$ verified the construction of pET:ChiII (Fig. 1).

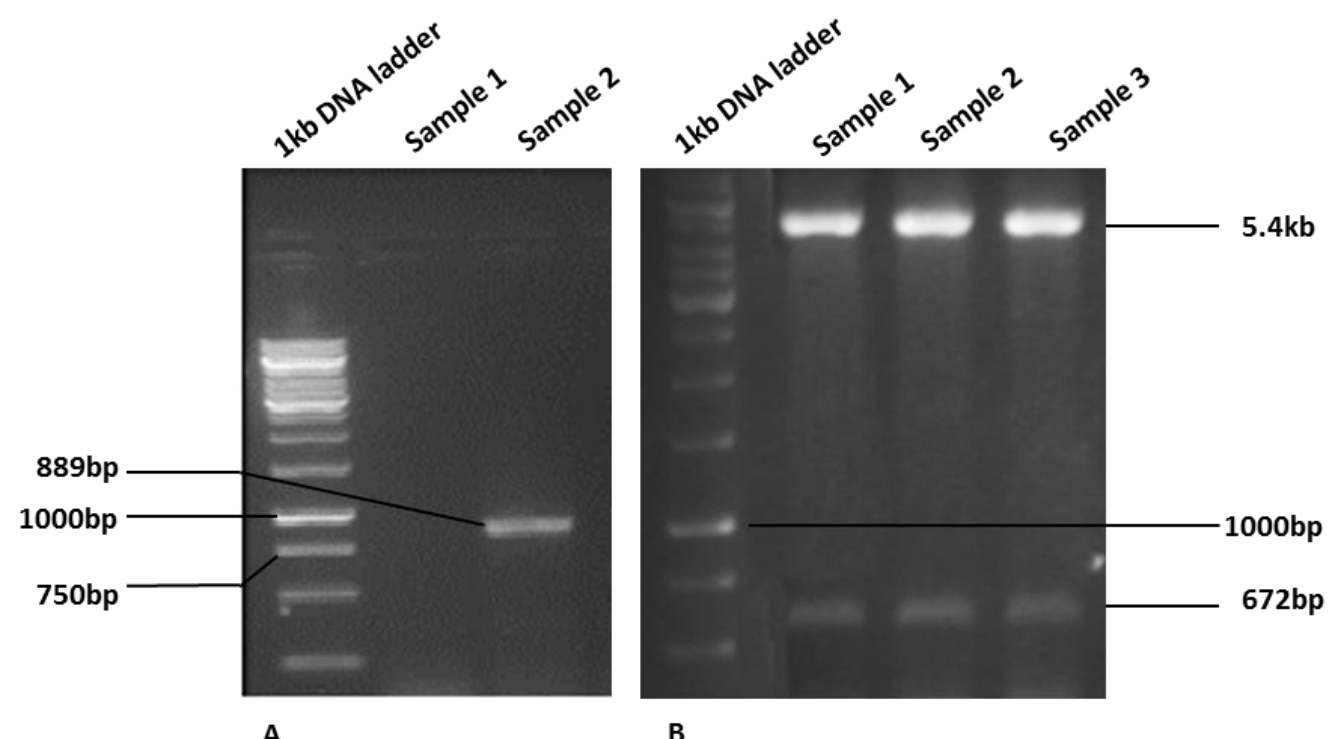

Figure 1. Amplification and restriction digestion of chitinase gene. A) amplification of chitinase gene from barley, lane $1=1 \mathrm{~Kb}$ ladder, lane $2=$ negative control, lane $3=$ amplification of 889 $b p$ gene from barley. B) restriction digestion of chitinase gene into $p E T$ vector $30 a$, lane1 = $1 \mathrm{~Kb}$ ladder, lane 2-4 = Restriction digestion of potential pET clones to verify the construct 
Several transformed colonies of BL21 strain were selected for recombinant protein expression onto SDS-PAGE. Out of total 22 colonies selected, only three were selected for further expression enhancement. Recombinant proteins over-expressed in bacteria often form insoluble proteins called inclusion bodies. It was found that recombinant chitinase protein was present inside the inclusion bodies while expressing in the E. coli host. Maximum expression of the recombinant chitinase protein was achieved when samples were induced with $0.5 \mathrm{mM}$ IPTG while optimized induction time was $4 \mathrm{~h}$. Figure 3 depicts the expression patterns of all three selected colonies. A Clear difference in the expression pattern of induced versus uninduced sample can be seen (Fig. 2). For each treated colony, the recombinant protein expressed more as compared to the control, un-induced sample. However, maximum expression was achieved in colony \# 2 where unwanted proteins did not express (Fig. 2). Subsequently, colony \# 2 was selected for purification through column chromatography.

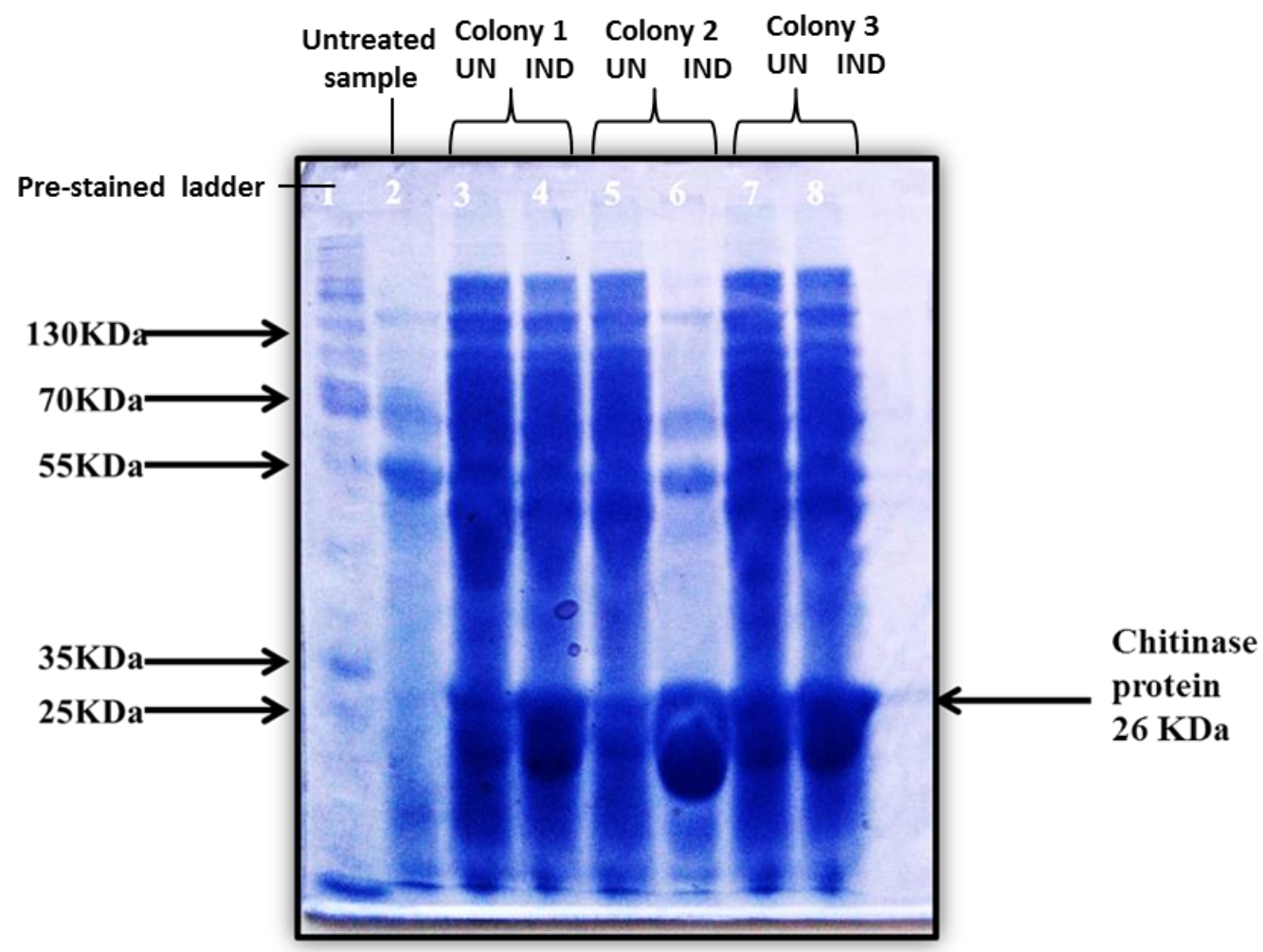

Figure 2. SDS-PAGE of crude protein samples showing recombinant protein expression in different induced/uninduced colonies of BL21 strain. Un-induced cultures were also run in parallel. In each well, approximately $10 \mu \mathrm{g}$ protein was loaded while pre-stained protein marker was used to define protein size. In the figure, UN refers to uninduced colony culture and IND refers to induced culture of the same colon while in total, three colonies were screened for expression of the recombinant protein

As the recombinant protein was present in inclusion bodies, purification of the protein was convenient. The inclusion bodies were purified to avoid co-purification of contaminants. Solubilization was done by $6 \mathrm{M}$ guanidine $\mathrm{HCl}$ and further subjected to refolding after elution using Ni-NTA IMAC purification system. The purified protein was resolved on $12 \%$ SDS-PAGE followed by western blotting using anti- His antibodies as shown in Fig. $3 A$ and $B$. 


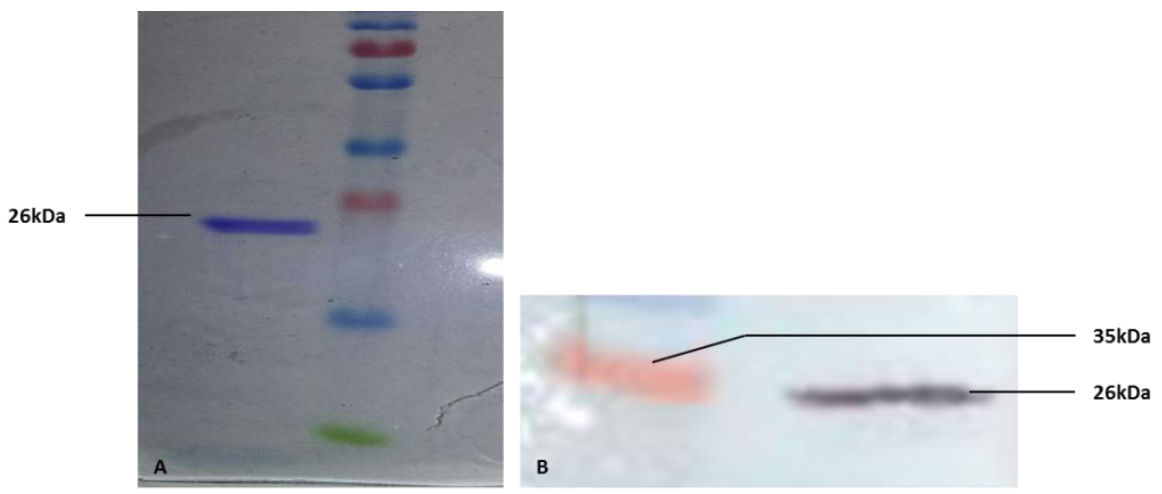

Figure 3. A) Purification of the recombinant chitinase protein purified through IMAC fast flow affinity chromatography. A single purified protein fraction at $26 \mathrm{kDa}$ was obtained. B) Western

blot of chitinase protein over-expressed in BL 21 strains. The blot was developed through antigen antibody reaction where Histag anti-rabbit primary antibody and secondary goat antirabbit AP conjugated antibody were used

\section{Recombinant chitinase protein inhibited the hyphal growth to a significant extent}

In in vitro qualitative assay, cylinder plate antifungal assay was performed where three phytopathogenic fungi; Rhizoctonia solani, Alternaria alternate and Fusarium oxysporum were tested against purified protein. Pathogen inhibition assay revealed that recombinant chitinase protein was effective in controlling the inoculated fungi. Growth retardation of Rhizoctonia solani was inhibited to a significant extent when treated with purified protein at $100 \mu \mathrm{g}$ concentrations while fungus inhibition was more as compared to the $70 \mu \mathrm{g}$ concentration of the protein where relatively less inhibition was observed. While in control sample, no inhibition was observed at all. Similar findings were met when Alternaria alternate and Fusarium oxysporum were inoculated and treated with purified recombinant protein. Maximum inhibition of the fungi growth was achieved at $100 \mu \mathrm{g}$ protein concentration; less was in $70 \mu \mathrm{g}$ concentration as compared to the control sample where no inhibition was observed (Fig. 4A, B and C). Conclusively, the fungus inhibition was found to be directly linked with increasing concentration of the recombinant protein, as, at maximum protein dose $(100 \mu \mathrm{g})$, fungus inhibition was maximum.

In the in-vitro quantitative antifungal assay, percentage reduction of hyphal growth in A. alternate was $40 \%$ at a $30 \mu \mathrm{g}$ concentration of the purified recombinant chitinase protein; $52 \%$ at $50 \mu \mathrm{g} ; 78 \%$ at $70 \mu \mathrm{g} ; 82.6 \%$ at $100 \mu \mathrm{g}$ protein concentration (Fig. 5A). Similarly, purified recombinant chitinase protein inhibited the hyphal growth of $R$. solani maximally at a100 $\mu \mathrm{g}$ concentration where inhibition was $77 \%$ while the percentage inhibition was 42,62 and 76 at $30 \mu \mathrm{g}, 50 \mu \mathrm{g}$ and $70 \mu \mathrm{g}$ protein concentration (Fig. 5B). In parallel, chitinase protein reduced the hyphal growth of Fusarium to 78\% at $70 \mu \mathrm{g}$ and $100 \mu \mathrm{g}$ concentrations while comparatively less reduction was observed at $30 \mu \mathrm{g}$ and $50 \mu \mathrm{g}$ protein concentration where inhibition was $52 \%$ and $66.6 \%$ (Fig. 5C). The findings of in vitro quantitative assay showed that there was a significant difference among control and different concentrations in standard value. $(\mathrm{P}<0.05 ; \mathrm{n}=3)$. In summary, at $70 \mu \mathrm{g}$ and above a concentration of the protein, fungal growth was inhibited maximally and the fungi were unable to grow across the well while at lower concentrations, the reduction was observed at a lesser extent. The control, untreated sample did not exhibit any inhibitory effect and the respective fungus grows maximally. 


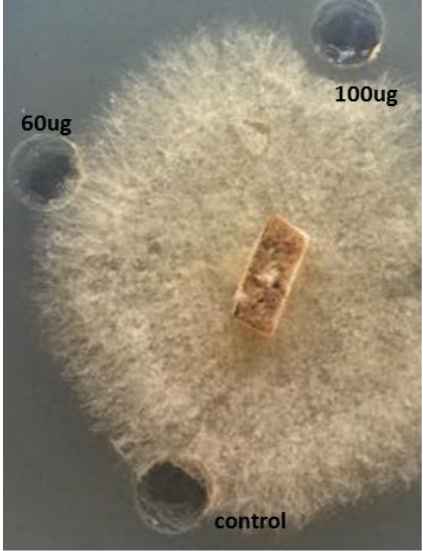

Rhizoctonia solani

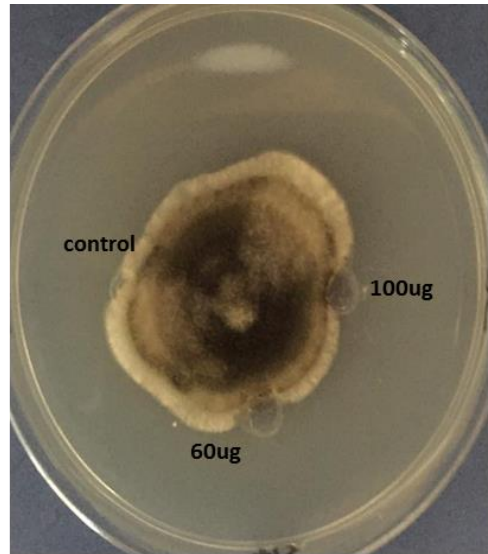

Alternaria solani

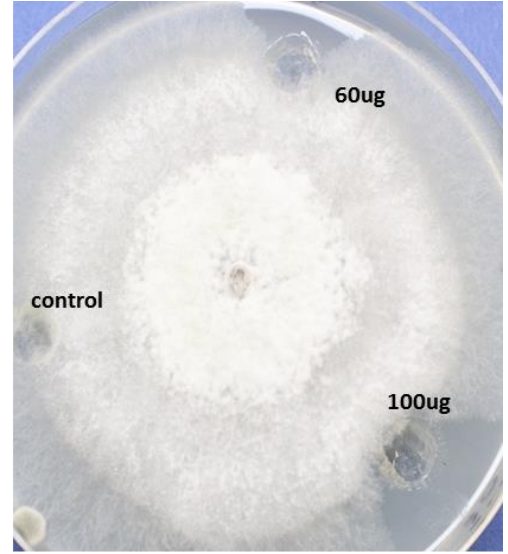

Fusarium spp

Figure 4. In-vitro fungal inhibition assay. Alternaria alternata, Rhizoctonia solani and Fusarium oxysporum were tested in qualitative assay against purified recombinant chitinase protein. Zone of inhibition are clearly visible

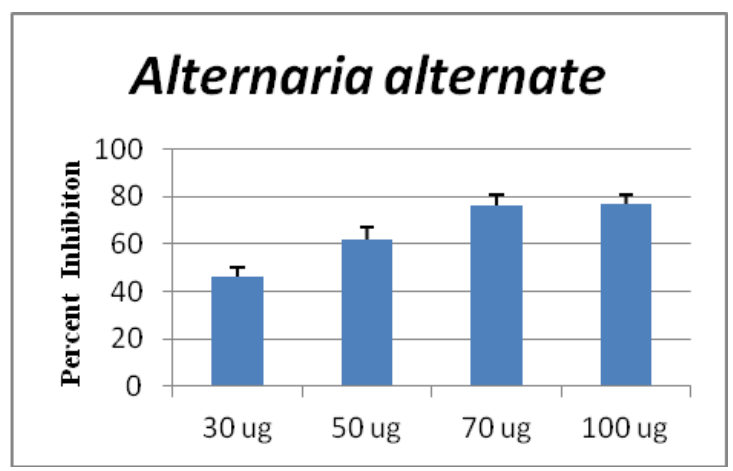

A

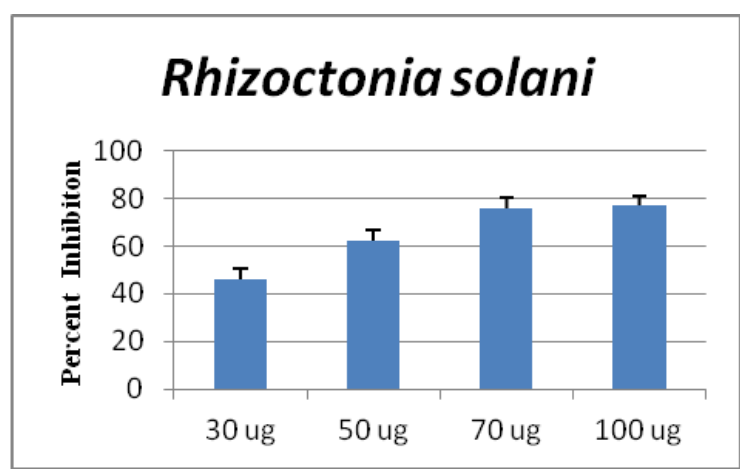

B

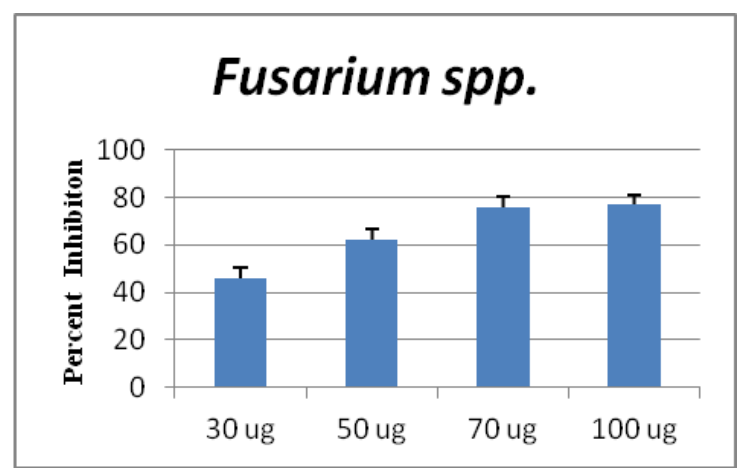

C

Figure 5. A) Percentage reduction in the hyphal growth of Alternaria alternate exhibited by the purified recombinant chitinase protein. B) Percentage reduction in the hyphal growth of Rhizoctonia solani exhibited by the purified recombinant chitinase protein. C) Percentage reduction in the hyphal growth of Fusarium oxysporum exhibited by the purified recombinant chitinase protein. The data were obtained in in-vitro quantitative antifungal assays. Control sample did not exhibit any reduction. The y-axis represents percentage inhibition percentage of fungi while the $x$-axis represents different concentration of purified chitinase. The bars represent the standard deviation. Statistically, the results showed that there was significant difference among control and different concentrations in standard value. $(P<0.05 ; n=3)$ 


\section{Discussion}

The aim of the present study was to isolate a plant based chitinase gene, characterize it and express it into the E. coli BL21 strain. The full-length gene was successfully isolated from total RNA of barley. Roberts and Selitrennikoff (1988) proposed that bacterial chitinases are difficult to interact with fungal cell wall so they have less resistance against fungi, whereas plant chitinases show high antifungal activity. The plant chitinases are usually endochitinases and contain lysozyme activity (Islam and Datta, 2015). In contrast, the bacterial enzymes are exochitinases and hydrolysed the chromogenic trisaccharide analogue as a substrate (Horn et al., 2006; Roberts and Selitrennikoff, 1988; Toufiq et al., 2018). So plant chitinases are usually preferred for increasing antifungal activity in the host. For this purpose, a plant chitinase was selected in this study.

Subsequently, we over-expressed chitinase gene in $E$. coli host and after purification of recombinant protein, the inhibitory effect against the three most devastating pathogenic fungi was evaluated in-vitro. The purified recombinant protein was used for inhibition of Rhizoctonia solani, Alternaria alternate and Fusarium oxysporum Different studies showed the inhibitory effect of chitinases in-vitro against fungi containing chitin. Kirubakaran and Sakthivel (2007) used class 1 chitinase from barley to inhibit pathogenic fungi of broad range in-vitro. In another study, Eissa et al. (2017) showed protection of transgenic wheat by using class II chitinase from barley seeds, against powdery mildew. Similarly, Liu et al. (2013) expressed two chitinase genes, LbCHI31 and LbCHI32 from Limonium bicolor in E. coli and reported their antifungal activity against Alternaria alternate. While Shenoy et al. (2006) have reported a $29 \mathrm{kDa}$ chitinase with antifungal activity in the bulbs of plant Urginea indica. Additionally, Garg and Gupta (2010) purified chitinase from moth bean having an inhibitory effect on Macrophomina phaseolina strain 2165. Tariq et al. (2018) transformed chitinase II gene to sugarcane and obtained significant resistance against $C$. falcatum compared to control. While Khan et al. (2018) expressed plant chitinase II gene and developed potato variety resistant to $A$. solani.

\section{Conclusion}

Conclusively, the potential inhibitory effect of barley derived chitinase II gene was exploited against phyto-pathogenic fungi which, in future, can be used to develop transgenic plants tolerant towards these devastating fungal pathogens.

Acknowledgements. This research work was funded by Higher Education Commission (HEC), Pakistan under "Indigenous Ph.D. Fellowship' scheme".

\section{REFERENCES}

[1] Becker, K., Aimanianda, V., Wang, X., Gresnigt, M., Ammerdorffer, A., Jacobs, C., Gazendam, R., Netea, M., Latgé, J., van de Veerdonk, F. (2016): Aspergillus cell wall chitin induces anti-and proinflammatory cytokines in human PBMCs via the $\mathrm{Fc}-\gamma$ receptor/Syk/PI3K pathway. - MBio 7: e01823-01815. 
[2] Bentley, A., Cromey, M., Farrokhi-Nejad, R., Leslie, J., Summerell, B., Burgess, L. (2006): Fusarium crown and root rot pathogens associated with wheat and grass stem bases on the South Island of New Zealand. - Australasian Plant Pathology 35: 495-502.

[3] Cushion, M. T., Ashbaugh, A., Hendrix, K., Linke, M. J., Tisdale, N., Sayson, S. G., Porollo, A. (2018): Gene expression of pneumocystis murina after treatment with anidulafungin results in strong signals for sexual reproduction, cell wall integrity, and cell cycle arrest, Indicating a requirement for asci formation for proliferation. - Antimicrobial Agents and Chemotherapy AAC: 02513-02517.

[4] Eissa, H. F., Hassanien, S. E., Ramadan, A. M., El-Shamy, M. M., Saleh, O. M., Shokry, A. M., Abdelsattar, M., Morsy, Y. B., El-Maghraby, M. A., Alameldin, H. F. (2017): Developing transgenic wheat to encounter rusts and powdery mildew by overexpressing barley chi26 gene for fungal resistance. - Plant Methods 13: 41.

[5] Fesel, P. H., Zuccaro, A. (2016): $\beta$-glucan: Crucial component of the fungal cell wall and elusive MAMP in plants. - Fungal Genetics and Biology 90: 53-60.

[6] Garg, N., Gupta, H. (2010): Isolation and purification of fungal pathogen (Macrophomina phaseolina) induced chitinase from moth beans (Phaseolus aconitifolius). - Journal of Pharmacy and Bioallied Sciences 2: 38.

[7] Horn, S., Sørlie, M., Vaaje-Kolstad, G., Norberg, A., Synstad, B., Vårum, K., Eijsink, V. (2006): Comparative studies of chitinases A, B and C from Serratia marcescens. Biocatalysis and Biotransformation 24: 39-53.

[8] Islam, R., Datta, B. (2015): Diversity of chitinases and their industrial potential. - Int J Appl Res 1: 55-60.

[9] Jitonnom, J., Lee, V. S., Nimmanpipug, P., Rowlands, H. A., Mulholland, A. J. (2011): Quantum mechanics/molecular mechanics modeling of substrate-assisted catalysis in family 18 chitinases: conformational changes and the role of Asp142 in catalysis in ChiB. - Biochemistry 50: 4697-4711.

[10] Kaonga, C., Chidya, R., Kosamu, I., Abdel-Dayem, S., Mapoma, H., Thole, B., Mbewe, R., Sakugawa, H. (2018): Trends in usage of selected fungicides in Japan between 1962 and 2014: a review. - International Journal of Environmental Science and Technology 15: 1801-1814.

[11] Khan, A., Nasir, I. A., Tabassum, B., Aaliya, K., Tariq, M., Rao, A. Q. (2017): Expression studies of chitinase gene in transgenic potato against Alternaria solani. - Plant Cell, Tissue and Organ Culture (PCTOC) 128: 563-576.

[12] Kirubakaran, S. I., Sakthivel, N. (2007): Cloning and overexpression of antifungal barley chitinase gene in Escherichia coli. - Protein expression and purification 52: 159-166.

[13] Kruger, N. J. (2002): The Bradford Method for Protein Quantitation. - In: Walker, J. M. (ed.) The Protein Protocols Handbook. - Humana, New York, pp. 15-21.

[14] Lincoln, J. E., Sanchez, J. P., Zumstein, K., Gilchrist, D. G. (2018): Plant and animal PR1 family members inhibit programmed cell death and suppress bacterial pathogens in plant tissues. - Molecular Plant Pathology 19(9): 2111-2123.

[15] Liu, Z., Huang, Y., Zhang, R., Diao, G., Fan, H., Wang, Z. (2013): Chitinase genes LbCHI31 and LbCHI32 from Limonium bicolor were successfully expressed in Escherichia coli and exhibit recombinant chitinase activities. - The Scientific World Journal. http://dx.doi.org/10.1155/2013/648382.

[16] Melzer, M. S., Yu, H., Labun, T., Dickson, A., Boland, G. J. (2016): Characterization and pathogenicity of Rhizoctonia spp. from field crops in Canada. - Canadian Journal of Plant Pathology 38: 367-374.

[17] Munkvold, G. P. (2017): Fusarium species and their associated mycotoxins Mycotoxigenic Fungi. - Methods Mol. Biol. 1542: 51-106.

[18] Nakkeeran, S., Renukadevi, P., Aiyanathan, K. (2016): Exploring the Potential of Trichoderma for the Management of Seed and Soil-Borne Diseases of Crops. - In: Muniappan, R., Heinrichs, E. A. (eds.) Integrated Pest Management of Tropical Vegetable Crops. Springer, Dordrecht, pp. 77-130. 
[19] Oerke, E.-C. (2006): Crop losses to pests. - The Journal of Agricultural Science 144: 3143.

[20] Plascencia-Jatomea, M., Viniegra, G., Olayo, R., Castillo-Ortega, M. M., Shirai, K. (2003): Effect of chitosan and temperature on spore germination of Aspergillus niger. Macromolecular Bioscience 3: 582-586.

[21] Ramirez-Cabral, N. Y. Z., Kumar, L., Shabani, F. (2018): Suitable areas of Phakopsora pachyrhizi, Spodoptera exigua, and their host plant Phaseolus vulgaris are projected to reduce and shift due to climate change. - Theoretical and Applied Climatology. DOI: 10.1007/s00704-018-2385-9 1-16.

[22] Roberts, W. K., Selitrennikoff, C. P. (1988): Plant and bacterial chitinases differ in antifungal activity. - Microbiology 134: 169-176.

[23] Shenoy, S. R., Kameshwari, M., Swaminathan, S., Gupta, M. (2006): Major antifungal activity from the bulbs of Indian squill Urginea indica is a chitinase. - Biotechnology Progress 22: 631-637.

[24] Stadlinger, N., Berg, H., Van den Brink, P. J., Tam, N. T., Gunnarsson, J. S. (2018): Comparison of predicted aquatic risks of pesticides used under different rice-farming strategies in the Mekong Delta, Vietnam. - Environmental Science and Pollution Research 25: 13322-13334.

[25] Tariq, M., Khan, A., Tabassum, B., Toufiq, N., BHATTI, M., Riaz, S., NASIR, I., Husnain, T. (2018): Antifungal activity of chitinase II against Colletotrichum falcatum Went. causing red rot disease in transgenic sugarcane. - Turkish Journal of Biology 42: 45-53.

[26] Toufiq, N., Tabassum, B., Bhatti, M. U., Khan, A., Tariq, M., Shahid, N., Nasir, I. A., Husnain, T. (2018): Improved antifungal activity of barley derived chitinase I gene that overexpress a $32 \mathrm{kDa}$ recombinant chitinase in Escherichia coli host. - Brazilian Journal of Microbiology 49: 414-421.

[27] van Lenteren, J. C., Bolckmans, K., Köhl, J., Ravensberg, W. J., Urbaneja, A. (2018): Biological control using invertebrates and microorganisms: plenty of new opportunities. BioControl 63: 39-59. 